\title{
PREFACE
}

This book is the result of a project originally much more narrowly circumscribed: it aimed to trace the theoretical discussions of the period (from approximately 1250 to 1320 ) that led to William of Ockham's theory of mental language (oratio mentalis). At the time, I was guided by two motivations that I feel it is appropriate to describe here, as they remained decisive throughout my research.

On the one hand, I asked myself whether these scholastic debates, seemingly so different from our own and quite often conducted in a theological context, nonetheless had some relation to the problem of the "language of thought" that is treated in contemporary cognitive science. The very possibility of an intellectual conversation with authors as distant from us as the medievals was called into question in the 196os, thanks to the spectacular success of such notions as rupture, incommensurability, and paradigm shift. But perhaps the conclusions and hypotheses of Thomas Kuhn and Michel Foucault have been too readily accepted. The question, it seems to me, should be addressed in terms of detailed analyses of particular cases; indeed, the topic of mental language would especially seem to demand such treatment.

On the other hand, recent work by historians of ideas-in particular, William Courtenay, Zenon Kaluza, and Katherine Tachau-has forcefully demonstrated the need to reevaluate the place of William of Ockham in the history of later medieval philosophy, as well as the impact of his work on his immediate contemporaries and successors. Tachau, for example, maintained (in an important work that appeared in 1988, Vision and Certitude in the Age of Ockham) that the Ockhamist theory of knowledge was quite poorly received in the universities of the day and did not lead to the establishment of a philosophical school. However, Tachau's inquiry was restricted to select themes-namely, those surrounding intuitive cognition (notitia intuitiva) and the mental image (the species). It seemed to me that a similar study of the idea of mental language, central for the venerabilis inceptor, could perhaps act as a counterweight and in any case would provide a useful completion of the portrait. My hypothesis was-and still is - that William of Ockham accomplished, in the years 1315-25, a major and highly influential theoretical revolution, precisely through the development of the concept of oratio mentalis.

It quickly became clear, however, that I would need to move beyond the limited chronological frame to which I had initially confined myself in order to allow a detailed reexamination of the topic's Greek, Roman, patristic, and Arab sources, as well as of the entire medieval development of the theme since Anselm of Canterbury in the eleventh century. For not only did the texts of Aristotle, Augustine, Boethius, and John Damascene (as well as those of Anselm), on 
this topic and others, influence later reflection, but further, no recent work in the history of classical notions of logos endiathetos and verbum cordis provided an overview that could supply adequate background for my projected inquiry. It was thus necessary for me to venture-with fear and trembling!-into territory with which I was initially less familiar. With that, the feasibility of the enterprise became much less obvious. I believed that I ought to persist, despite the obstacles, only because I was convinced, on the basis of my readings and numerous discussions with colleagues, that it was necessary to evaluate, in a synthetic manner, the large question of interior discourse in ancient and medieval thought. Inevitably, errors will have escaped my attention. I only hope that the completed work will appear, as I believe, sufficiently fruitful that others might be willing to supplement or correct it where needed.

In any case, the project would never have succeeded without the continuing support of the Social Sciences and Humanities Research Council of Canada, the Quebec Fund for the Formation of Scholars and the Advancement of Research (FCAR), and the Institutional Research Fund of the University of Quebec in Trois-Rivières. My recognition of these organizations is all the greater for their generous help in permitting many assistants to accompany and stimulate my research, some over many months, others for several years. Here I wish to thank warmly all those students who were indispensable to the work of the bibliography, documentation, and analysis: Ivan Bendwell, Luc Bergeron, Richard Caron, Mario Charland, Guy Hamelin, Marcelo Lannes, Sylvie Laramée, Renée Lavergne, Maxime Lebeuf, André Leclerc, Lyne Neault, Patricia Nourry, and Gilles Ouimet.

I also wish to express my sincerest gratitude to others who helped me in various ways: Jennifer Ashworth, Sten Ebbesen, Russell Friedman, Elizabeth Karger, Alain de Libera, Jean-Marc Narbonne, Calvin Normore, Irène RosierCatach, and Joke Spruyt have all had the kindness to provide, in some form or other, detailed comments on one or another part of my research; at the beginning of my work, Jean-François Le Gal kindly gave me many days' access to the remarkable files of the glossary of medieval Latin philosophy at the Sorbonne; over the years, Cécile Juneau has typed each chapter of the book, with as much efficiency as patience as I constantly provided innumerable corrections; Christian Dunn closely read a complete version of the work, and I have benefited in many places from his acute sense of the French language; Thierry Marchaisse, of Éditions du Seuil, kept me on track with valuable advice; finally, throughout this process, my companion, Claude-Elizabeth Perreault, provided considerable technical help in the matter of the bibliography and word processing, as well as crucial and unswerving personal support.

\section{TECHNICAL EXPLANATION}

For bibliographic references, I have employed a twofold system that appeared to me the most economical under the circumstances. Editions and translations 
used for ancient and medieval sources are indicated in the notes, with a complete description at their first occurrence; the reader will easily find them with the help of the index of names. On the other hand, in the notes for modern works only, I have given the names of authors and dates of publication, while the complete entry can be found in the bibliography at the end of the volume.

When no translator is mentioned in the citations, the French translation of the passage in question is my own.

Lac des Érables, October 1998 
This page intentionally left blank 
MENTAL LANGUAGE 
This page intentionally left blank 